\title{
SOME NEW SPECIES OF COLEOPTERA IN THE TRING MUSEUM.
}

\author{
By W. F. ROSENBERG.
}

\section{CERAMBYCIDAE.}

\section{Poecilopeplus martialis sp. nov.}

\begin{abstract}
Head coarsely punctured, a deep longitudinal groove in centre, not reaching to base.

Thorax black; disc with five slightly raised flattened tubercles, a lateral tooth as in $P$. favescens, but not so strongly developed; anterior angle rounded, less produced than in favescens; surface coarsely punctured except on raised portions of dise, which are nearly smooth.

Elytra closely punctured, rugosely punctate at base; humeral angle not so much raised as in P. flavescens. Straw-yellow; a black transverse band at base, not quite extending to suture, narrowest laterally, not quite reaching margin; a second transverse black band before the middle, extending from the margin, but not reaching the suture; a third band situated at three-fifths of the distance from the base, and a large triangular black spot at the apex.

Under surface and legs black; tarsi beneath dark brown.

Long. $32 \mathrm{~mm}$; lat. hum. $13 \mathrm{~mm}$; antennae $18 \mathrm{~mm}$.

Hab. Costa Rica. Type in the Tring Museum, under the above name, which I have adopted. It may be distinguished from $P$. Alavescens by the very different position of the third band on the elytra and by the apical spot; all the bands are much broader and regular in shape.
\end{abstract}

\section{Poecilopeplus flavescens sp. nov.}

Head closely punctured, smoother on top. Thorax black, dilated at sides; a blunt tooth-like lateral process abont the middle; anterior angles well prodnced, rounded; sides slightly depressed above lateral tooth; centre of disc raised; a slight tubercle on each side of disc, near the base and above lateral tooth; both margins ridged; surface deeply punctate, except on raised portion of disc.

Scutellum black, finely punctured.

Elytra with three fine longitudinal raised lines, the inner one commencing at the edge of the black basal band, gradually inclining towards the suture but not tonching it; it does not quite reach the apex; the second commences above the ridge of the humeral angle and runs parallel to the first; it is a little longer and is forked at the end; the outer line has its origin behind the humeral angle, and is very short, becoming lost on entering the second black band. The humeral angles are raised longitudinally. Surface of elytra thickly punctured, with several depressions between the basal band and the middle one. General colour "gallstone yellow" (Ridgway); a broad irregularly shaped transverse black band at base, not quite 
extending to the suture; a second black band before the middle, consisting of two angulated spots, joined in the type, but separated in a second specimen; this band commences at the margin, but does not quite reach the suture; a third black band, diagonally transverse, commencing at the margin at about three-fourths of its length from the base; it is much shorter than the middle band, and is also composed of two angulated spots joined together; it is continued on the margin into a narrow border which reaches the apex and extends a little way up the suture.

Under surface and legs black; soles dark brown.

Long. $28 \mathrm{~mm}$.; lat. hum. $11 \mathrm{~mm}$.; antennae $17 \mathrm{~mm}$. 3500 feet.

Hab. Taken by myself at Paramba, Ecnador, April 1897, at an elevation of

\section{HISPIDAE.}

\section{Alurnus costalis sp. nov.}

Thorax thickly covered with a grey pubescence ; transversely deeply depressed, rugosely punctate, strongly convex in front, sides slightly depressed at apex; an obtuse tooth at posterior angles.

Antennae black, half the length of the body, third joint more than twice the length of the fourth.

Scutellum black, coarsely punctate.

Elytra much broader than thorax, margined, slightly sinuate below the shoulders; humeral process well developed; six strongly marked costae, distributed as follows : the first commencing at the base and running along the whole of the suture; the second also commencing at the base, confluent with the first for a little distance, then running independently for about a fifth of the length of the elytra, where it again merges into the first; the third starting from the base of the elytra at the same point as the first and second, inclining towards the suture for about half its length, whence it runs parallel to it; the fourth also starting from the base, but not becoming prominent until passing the humeral process; the fifth commencing behind the humeral process, the sixth at the outer base of the shoulders. All the costae show a tendency to converge towards the apical angle, but are lost before reaching that point; the first, third, and fifth are the longest. The spaces between the costae are thickly punctate, the coarsest punctures being at the base; there are occasional punctures in the costae themselves. The elytra are ochre-yellow in colour for slightly more than half their length from the base, the remainder being blood-red; the costae, however, are yellow for their entire length, running over the red portion of the elytra in the form of stripes.

Legs and under surface black; soles reddish brown. Under surface and tibia thinly covered with a greyish pubescence.

Long. $33 \mathrm{~mm}$; lat. hum. $12 \mathrm{~mm}$; antennae $13 \mathrm{~mm}$.

Hab. West coast of Colombia and Ecuador.

The type, now in the possession of the Hon. W. Rothschild, was taken by me at Juntas, Rio Dagua, Colombia, in 1895, crawling on a tree-trunk, near the ground; I never saw another example in that place. In January $1897 \mathrm{I}$ took a specimen at Cachabí, N.W. Ecuador. In Febrnary of the same year I took a third example of the species, on the road from Cachabí to Paramba; in this the red is confined to rather less than the apical half of the elytra, but it covers the whole of those parts of the costae contained within that space. In both the Ecuadorian specimens the thorax is black, 
but with distinct traces of the pubescence, which has probably been rubbed off. The most prominent character of the species is the presence of the strongly marked costae on the elytra.

Those from Ecnador were taken sitting on the leaves of low plants.

\section{Alurnus humeralis sp. nov.}

Head and antennae black. Thorax transverse, centre convex, sides of disc depressed; a well-prodnced tooth on posterior angle; surface rugosely punctate, less marked on convex portion; colour deep red, margin of base black.

Scutellum black, punctate.

Elytra broader than thorax, slightly sinuate below shoulders, margin slightly reflexed, rugosely pnnctate at base, the punctation becoming finer towards apex; humeral process well developed. Pearly white, a black spot on humeral process, surrounded by a reddish ring; a black spot on each elytron behind the centre.

Legs and under surface black; soles reddish brown.

Long. $35 \mathrm{~mm}$; lat. hum. $13 \mathrm{~mm}$; antennae $13 \mathrm{~mm}$.

Hab. Cachabí and Paramba, N.W. Ecnador. Generally taken at rest on leaves of low plants ; frequently seen on sunny days flying at a considerable height.

Nearest to A. saundersi, but may be at once distinguished by the humeral spots, and by the position of those on the elytra, which are behind the middle in A. humeralis, whilst they are before the middle in A. saundersi.

Some specimens have the apical margin of the thorax black; one or two of these have the black basal and apical margin connected by a black streak along the centre of the disc. A few specimens have only the centre of the scutellum black, the remainder being red; in one of these the hnmeral spots are also red. The reddish ring which surrounds the humeral spot varies considerably in extent, in some cases being almost obsolete, whilst in one or two specimens it margins the whole base of the elytra. There is also much variation in the size of the central spots of the elytra, but their position is always the same. The type has a narrow dark brown line on the apical margin of the elytra, but this is absent in many specimens. The humeral spots are constant.

The elytra are pearly white in living specimens, but become yellowish when they are dried.

\section{Alurnus boucardi sp. nov.}

Head black, rugosely punctate in front. Antennae less than half the length of the body. Thorax entirely black, sides dilated, anterior angle obtuse; posterior half slightly depressed laterally, rugose-punctate behind, punctured in front.

Scutellum black, thickly punctate.

Elytra pale yellow (probably white in living specimens, as in A. humeralis); general shape similar to $A$. saundersi, but humeral process rather more produced; strongly marked costae are present, but they are not so pronounced as are those of A. costalis; surface coarsely punctate, the punctures becoming finer towards apex; a rather large black spot behind the middle of each elytron.

Legs black; soles light brown.

Long. $32 \mathrm{~mm}$; lat. hom. $13 \mathrm{~mm}$.; antennae $13 \mathrm{~mm}$.

Hab. Colombia. Type in Tring: Museum, from Museum Boucard. 
Closely allied to A. dorbignyi Guer., but may be distinguished by the entirely black thorax, the well-developed costae, and the position of the spots on the elytra, which are situated even farther from the base than in A. lumeralis.

An Alurmus in the British Museum, from Veragua, seems to be referable to this species; it differs in the spots of the elytra being obsolete, but perfectly agrees in other respects.

\section{Alurnus sexguttatus sp. nov.}

Head and thorax shiny greenish black; head punctured, with a lunar-shaped excavation above; thorax subcylindrical, sides rounded, transversely depressed behind; front of disc convex, sides and depression rugosely punctate; convex portion of disc sparsely punctured; posterior angles not toothed.

Antennae black, third joint more than twice the length of the fourth.

Scutellum black, punctate.

Elytra parallel, rather strongly margined, apex evenly rounded; above convex, humeral process moderately developed; punctation close, evenly distributed, finer near apex. Colour pale tawny, with a reddish tinge at shoulders and sides; three small black spots on each elytron, distributed as follows : one immediately behind the humeral process; a second near the suture, at a little less than a third of the length from the base; and a third in the centre of the elytron, behind the middle. There is a narrow black line on the margin, commencing behind the humeral process and extending to the apex.

Underside, legs, inclusive of soles, black.

Long. $16 \mathrm{~mm}$; lat. hum. $7 \mathrm{~mm}$; antennae $8 \mathrm{~mm}$.

Hab. One specimen taken by myself on the road from Cachabi to Paramba, February 1897. 


\section{$2 \mathrm{BHL}$ Biodiversity Heritage Library}

Henry, Rosenberg William Frederick. 1898. "Some new species of Coleoptera in the Tring Museum." Novitates zoologicae : a journal of zoology in connection with the Tring Museum 5, 92-95. https://doi.org/10.5962/bhl.part.1647.

View This Item Online: https://www.biodiversitylibrary.org/item/22556

DOI: https://doi.org/10.5962/bhl.part.1647

Permalink: https://www.biodiversitylibrary.org/partpdf/1647

\section{Holding Institution}

Natural History Museum Library, London

\section{Sponsored by}

Natural History Museum Library, London

\section{Copyright \& Reuse}

Copyright Status: Public domain. The BHL considers that this work is no longer under copyright protection.

This document was created from content at the Biodiversity Heritage Library, the world's largest open access digital library for biodiversity literature and archives. Visit BHL at https://www.biodiversitylibrary.org. 